\title{
Oral health related knowledge, attitude and practice among nursing students of Kathmandu - a pilot study
}

\author{
Rosina Bhattarai, Sunita Khanal, G. Nagaraja Rao, Sujita Shrestha \\ Department of Community Dentistry, Kantipur Dental College, Dhapasi, Kathmandu, Nepal
}

\section{Correspondence \\ Dr. Rosina Bhattarai \\ Kantipur Dental College, \\ Dhapasi, Kathmandu, Nepal \\ Email: \\ rosinabhattarai@gmail.com}

DOI: http://dx.doi.org/10.3126/ jemsn.v12i4.15135

Article received: March $22^{\text {nd }}$ 2016

Article accepted: April $22^{\text {nd }}$

2016

\begin{abstract}
Background \& Objectives: The objective of the study was to assess the oral health related knowledge, attitude and practices of bachelors level nursing college students in Kathmandu district. Materials \& Methods: Data was collected using pre-designed questionnaire among 251 nursing students of three colleges comprising of 43 closed ended questions adopted from various studies. Twenty five questions related to knowledge, 8 questions of attitude and 10 of practice were asked. Prior to conducting the study permission was obtained from institutional review board of Kantipur Dental College and from the Campus Chief of the nursing colleges. Results: Majority of respondents had good oral health knowledge including functions of teeth $(94.0 \%)$, mineral important for tooth formation (98.4\%), vitamin necessary for growth and development of teeth $(91.2 \%)$, dental caries $(90.4 \%)$, gingival diseases $(96.4 \%)$ and treatment for malocclusion (90.8\%). Almost half of the participants did not know about treatment options for gum disease, consequences of irregular teeth and causes of oral cancer. Majority of the participants showed good attitudes towards oral health with $99.2 \%$ giving equal importance to their teeth like their general health. $78.9 \%$ of the participants brush twice daily with $98 \%$ using toothbrush and toothpaste among whom $65.7 \%$ uses soft bristle toothbrushes Conclusion: It was seen that oral health related knowledge, attitude and practice of nursing students was adequate but further improvements can be encouraged and facilitated.
\end{abstract}

Key words: Attitude, knowledge, nursing students, practice

Citation: Bhattarai R, Khanal S, Rao GN, Shrestha S. Oral health related knowledge, attitude and practice among nursing students of Kathmandu - a pilot study. JCMS Nepal. 2016;12(4):160-8.

\section{INTRODUCTION}

Health is the state of complete physical, mental and social well-being and not merely the absence of disease or infirmity. ${ }^{1}$ Health is a common theme in most cultures with remarkable emphasis on the fact that health is a fundamental human right and a worldwide social goal necessary for an improved quality of life. Oral health is the standard of health of the oral and related tissues which enables individual to eat, speak and socialize without active disease, discomfort or embarrassment and which contributes to general well-being. ${ }^{2}$ There have been rapid changes in the pattern of oral diseases during the past decade. ${ }^{3,4}$

One of the primary concerns of dental health care professionals is to impart positive oral health knowledge and behavior in the society and creating an environment conducive to shift the responsibility of public health from the shoulders of health professionals to the people's own hands. Students related to health franchise play an important role in oral health care and promotion. Nursing personnel also play a vital role in health promotion, preventive information dissemination and therefore it is important that their oral health knowledge be good so that the community can also get benefited eventually. Therefore, the aim of this study was to assess the oral health knowledge, attitude and practice (KAP) of nursing students of Kathmandu.

\section{MATERIALS AND METHODS}

Study design: A cross-sectional study was carried out using questionnaire adopted from studies by Senthil et $\mathrm{al}^{5}$ and Amith HV et $\mathrm{al}^{6}$. 
Ethical consideration and consent: Ethical consent was obtained from Institutional Review Board of Kantipur Dental College, Teaching Hospital and Research Centre. Prior permissions were taken from the Campus Chief of respective colleges. The participation in the study was voluntary, informed consent was obtained and all participants remained anonymous.

Collection of data: Data was collected from three different nursing colleges from Kathmandu having Bachelor's level nursing program in their curriculum. The students of Certificate level and Masters level nursing program were excluded. Colleges from where data was collected were Nobel College, School of Nursing, Sinamangal, Kathmandu Model Hospital School of Nursing, Swyambhu and Yeti Health Sciences Academy, Maharajgunj which were randomly selected from available list of colleges.

\section{STATISTICAL ANALYSIS}

The results were analyzed using Statistical Package for Social Sciences (SPSS) version 20. Descriptive statistics was obtained and frequency distribution, mean, range and standard deviation was calculated.

\section{RESULTS}

A total of 251 respondents, all females, participated in the study with age range of 17 to 31 years and mean age of 20.96. Out of total respondents, $74.5 \%$ i.e. 187 were B.Sc Nursing students while $25.5 \%$ i.e. 64 were $\mathrm{BN}$ students.

Table 1 show that out of 251 participants $94 \%$ had knowledge on functions of teeth, $98.4 \%$ on mineral important for tooth formation, $91.2 \%$ on vitamin important for growth and development of bones and teeth. Regarding chronology of tooth development $80.1 \%$ had knowledge on time of first tooth eruption, $54.6 \%$ on age of first permanent tooth eruption and $63.7 \%$ on number of deciduous teeth.

Table 2 shows knowledge about the most prevalent oral disease i.e. dental caries $70.1 \%$ knew what dental caries is with $90.4 \%$ having knowledge on how to notice it, $82.5 \%$ about the causes and $84.9 \%$ about their treatment. Knowledge on gingival diseases was found to be fairly adequate. $96.4 \%$ had knowledge on bleeding from gums, $98 \%$ on cause of bad breath whereas only $56.2 \%$ had knowledge on treatment of gingival diseases.

Table 3 shows $90.8 \%$ had knowledge on treatment of irregularly positioned teeth, while $44.2 \%$ had knowledge on consequences of irregularly positioned teeth. With regards to oral cancer, $73.3 \%$ had knowledge on oral cancer, $73.3 \%$ on signs of oral cancer, $51 \%$ on causes and $78.5 \%$ on treatment of oral cancer. Only $40.2 \%$ had knowledge on role of fluoride in dentistry. A total of $81.3 \%$ had knowledge regarding presence of fluoride in their toothpaste. About $62.9 \%$ know about sequalae of missing teeth while $41 \%$ know about various options to replace lost teeth.

Table 4 shows the attitudes of nursing students towards oral health. $16.7 \%$ keep their oral cavity clean by regular brushing while $83.3 \%$ both brush their teeth and rinse regularly. $99.2 \%$ believe brushing with brush and paste is a good habit. $98.8 \%$ think visiting dentists regularly is a good practice while $94.8 \%$ believe that a dentist can improve her appearance. However, only $86.5 \%$ want their irregularly positioned teeth to be treated by their dentist. A total of $98.8 \%$ agreed that tobacco chewing is a bad habit. With regards to acceptance of artificial denture, $86.1 \%$ believe it is well accepted by the society.

Table 5 shows that out of 251 students, 198 of them i.e. $78.9 \%$ brush their teeth twice daily. Table 6 shows that $98 \%$ use toothbrush and paste to brush their teeth. Table 7 shows $49 \%$ use mouth rinse, $34.7 \%$ use tongue cleaner, $16 \%$ use dental floss and $2.4 \%$ use interdental brush to clean their oral cavity. Table 8 shows $82.9 \%$ brush their teeth with a combination of horizontal, vertical and circular technique. Table 9 shows that $75.7 \%$ use plain water to rinse their mouth. Table 10 shows how frequently the nursing students visit their dentists. $58.6 \%$ visit dentist in case of any problem, $24.7 \%$ visit once a year, $11.6 \%$ visit twice a year and $4.4 \%$ visit once in two years.

Figure 1 shows that $65.7 \%$ use soft bristle brush while $25.1 \%$ use medium bristle and $7.6 \%$ use ultra -soft toothbrush to clean their teeth. Figure 2 shows that $64.5 \%$ change their toothbrush every one to three months. Figure 3 shows that $37.5 \%$ brush their teeth for two to three minutes, $20.7 \%$ for one to two minutes, $35.1 \%$ for three to four minutes and $6.4 \%$ for more than four minutes. Figure 4 shows that $49.8 \%$ use toothbrush while $42.6 \%$ use tongue scraper to clean their tongue.

\section{DISCUSSION}

Oral diseases are one of the major public health problems and since the nursing staffs and students reach out to the many underserved areas of the country, they are expected to have positive behavior towards oral health and its diseases. Our study 
Table 1: Knowledge on eruption and functions of teeth

\begin{tabular}{|c|c|c|c|}
\hline Questions & & Frequency & Percentage \\
\hline \multirow{5}{*}{ Function of teeth } & Good appearance & 1 & $0.0 \%$ \\
\hline & Efficient chewing & 10 & $0.03 \%$ \\
\hline & Pronounce properly & 1 & $0.0 \%$ \\
\hline & All of above & 236 & $94 \%$ \\
\hline & Not answered & 3 & $0.01 \%$ \\
\hline \multirow{4}{*}{$\begin{array}{l}\text { Mineral important for } \\
\text { tooth formation }\end{array}$} & Calcium & 247 & $98.4 \%$ \\
\hline & Zinc & 1 & $0.4 \%$ \\
\hline & Copper & 1 & $0.4 \%$ \\
\hline & Selenium & 2 & $0.8 \%$ \\
\hline \multirow{5}{*}{$\begin{array}{l}\text { Vitamin for growth and } \\
\text { development of bones }\end{array}$} & Vitamin A & 5 & $2.0 \%$ \\
\hline & Vitamin B & 5 & $2.0 \%$ \\
\hline & Vitamin D & 229 & $91.2 \%$ \\
\hline & Don’t know & 5 & $2.0 \%$ \\
\hline & Not answered & 7 & $2.8 \%$ \\
\hline \multirow{5}{*}{ First tooth erupts at } & 6 months & 201 & $80.1 \%$ \\
\hline & 1 year & 37 & $14.7 \%$ \\
\hline & 4 months & 10 & $4.0 \%$ \\
\hline & Don't know & 1 & $0.4 \%$ \\
\hline & Not answered & 2 & $0.8 \%$ \\
\hline \multirow{5}{*}{$\begin{array}{l}\text { Age of first permanent } \\
\text { tooth eruption }\end{array}$} & $4-5$ years & 20 & $8.0 \%$ \\
\hline & $6-7$ years & 137 & $54.6 \%$ \\
\hline & 12 years & 85 & $33.9 \%$ \\
\hline & Don't know & 6 & $2.4 \%$ \\
\hline & Not answered & 3 & $1.2 \%$ \\
\hline \multirow{5}{*}{$\begin{array}{l}\text { Number of deciduous } \\
\text { teeth }\end{array}$} & 15 & 21 & $8.4 \%$ \\
\hline & 22 & 41 & $16.3 \%$ \\
\hline & 20 & 160 & $63.7 \%$ \\
\hline & Don't know & 19 & $7.6 \%$ \\
\hline & Not answered & 10 & $4.0 \%$ \\
\hline
\end{tabular}



Figure 1: Type of toothbrush used

showed that the oral health related knowledge among nursing students of Kathmandu district was fairly adequate with some lack of knowledge in the field of oral cancer, fluorides and prosthetic rehabilitation.

It was seen that $96.4 \%$ had knowledge on unhealthy gums leading to their bleeding. However, in study

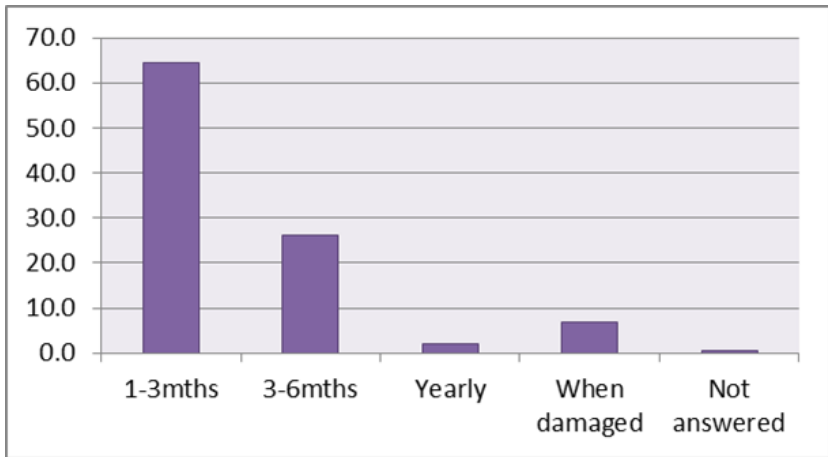

Figure 2: Frequency of change of toothbrush

conducted by Kaira LS et $\mathrm{al}^{3}$ among nursing students of Rohilkhand Medical College and Hospital, a good percentage i.e. $86.4 \%$ were aware regarding gingival and periodontal health. Only $40.2 \%$ of the students had knowledge regarding role of fluorides in dentistry in our study. Similarly, study by Usman et $\mathrm{al}^{7}$, conducted among clinical, 


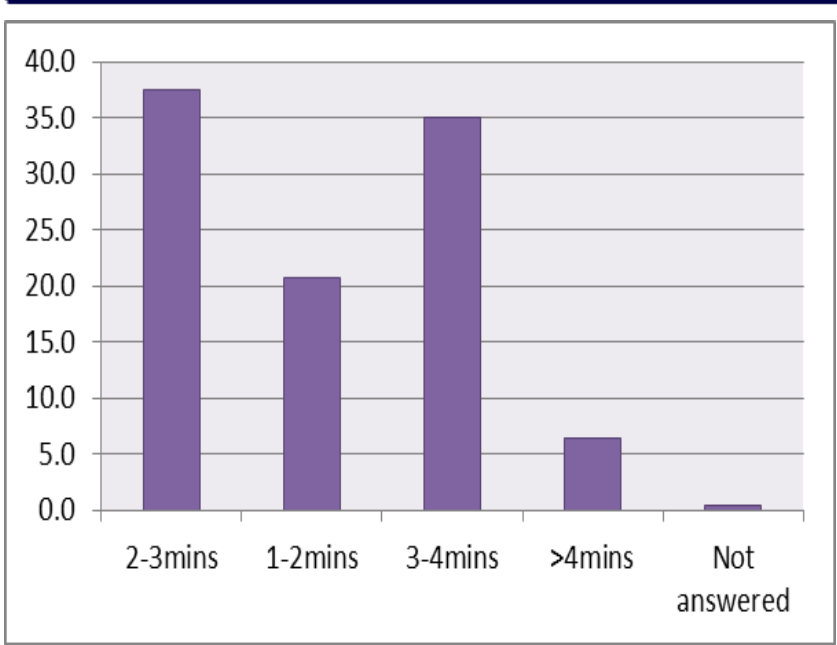

Figure 3: Duration of tooth brushing

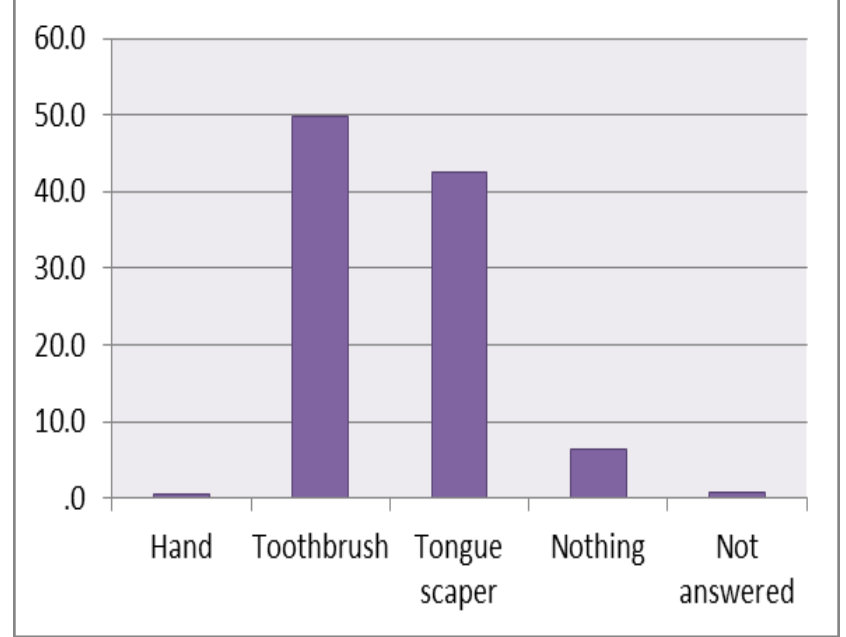

Figure 4: Methods used for cleaning tongue

Table 2: Knowledge on dental caries and gum diseases

\begin{tabular}{|c|c|c|c|}
\hline \multicolumn{2}{|l|}{ Questions } & Frequency & Percentage \\
\hline \multirow[b]{4}{*}{ Tooth decay } & Fractured tooth & $227^{*}$ & $90.4 \%$ \\
\hline & Discolored tooth & 18 & $7.2 \%$ \\
\hline & Destroyed tooth & 5 & $2.0 \%$ \\
\hline & Don't know & 1 & $0.4 \%$ \\
\hline \multirow[b]{4}{*}{ Notice tooth decay } & Black color with hole & 227 & $90.4 \%$ \\
\hline & Swollen gums & 18 & $7.2 \%$ \\
\hline & Fractured & 5 & $2.0 \%$ \\
\hline & Don't know & 1 & $0.4 \%$ \\
\hline \multirow[b]{4}{*}{ Causes of tooth decay } & Injury to tooth & 34 & $13.5 \%$ \\
\hline & Intake of more sweets & 207 & $82.5 \%$ \\
\hline & Over rinsing of mouth & 8 & $3.2 \%$ \\
\hline & Don't know & 2 & $0.8 \%$ \\
\hline \multirow{5}{*}{$\begin{array}{l}\text { Treatment of tooth } \\
\text { decay }\end{array}$} & Scaling & 19 & $7.6 \%$ \\
\hline & Clove oil dressing & 9 & $3.6 \%$ \\
\hline & Filling & 204 & $81.3 \%$ \\
\hline & Don't know & 18 & $7.2 \%$ \\
\hline & Not answered & 1 & $0.4 \%$ \\
\hline \multirow{4}{*}{$\begin{array}{l}\text { Prevention of tooth } \\
\text { decay }\end{array}$} & Regular tooth brushing & 31 & $12.4 \%$ \\
\hline & Visiting dentist & 2 & $0.8 \%$ \\
\hline & Rinsing mouth after meal & 5 & $2 \%$ \\
\hline & All of the above & 213 & $84.9 \%$ \\
\hline \multirow{4}{*}{ Bleeding from gums } & Tooth decay & 8 & $3.2 \%$ \\
\hline & Unhealthy gums & 242 & $96.4 \%$ \\
\hline & Healthy gums & 1 & $0.4 \%$ \\
\hline & Don't know & 0 & $0.0 \%$ \\
\hline \multirow{4}{*}{ Causes of bad breath } & Infected gums & 246 & $98.0 \%$ \\
\hline & Missing teeth & 2 & $0.8 \%$ \\
\hline & Don't know & 2 & $0.8 \%$ \\
\hline & Not answered & 1 & $0.4 \%$ \\
\hline \multirow{5}{*}{$\begin{array}{l}\text { Treatment for gum } \\
\text { disease }\end{array}$} & Scaling & 16 & $6.4 \%$ \\
\hline & Surgical treatment & 18 & $7.2 \%$ \\
\hline & Mouthwashes & 67 & $26.7 \%$ \\
\hline & All of the above & 141 & $56.2 \%$ \\
\hline & Not answered & 9 & $3.2 \%$ \\
\hline
\end{tabular}


Table 3: Knowledge on other oral conditions

\begin{tabular}{|c|c|c|c|}
\hline Questions & & Frequency & Percentage \\
\hline & Extraction & 5 & $2.0 \%$ \\
\hline Type of treatment for & Treatment with wire & 228 & $90.8 \%$ \\
\hline 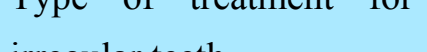 & Grinding of teeth & 3 & $1.2 \%$ \\
\hline & Don't know & 12 & $4.8 \%$ \\
\hline & Not answered & 3 & $1.2 \%$ \\
\hline & Dental decay & 24 & $9.6 \%$ \\
\hline Irregularly & Gum disease & 30 & $12.0 \%$ \\
\hline mositioned & Trauma & 84 & $33.5 \%$ \\
\hline & All of the above & 111 & $44.2 \%$ \\
\hline & Not answered & 2 & $0.8 \%$ \\
\hline & Small ulcer & 31 & $12.4 \%$ \\
\hline & Malignant lesion & 184 & $\mathbf{7 3 . 3 \%}$ \\
\hline & Decay tooth & 11 & $4.4 \%$ \\
\hline Oral cancer & Don’t know & 20 & $8.0 \%$ \\
\hline & Not applicable & 5 & $2.0 \%$ \\
\hline & Bleeding gums & 32 & $12.7 \%$ \\
\hline & Dental decay & 7 & $2.8 \%$ \\
\hline & Non-healing wound & 184 & $\mathbf{7 3 . 3 \%}$ \\
\hline Suspect oral cancer & Don't know & 23 & $9.2 \%$ \\
\hline & Not answered & 5 & $2.0 \%$ \\
\hline & Sharp edged teeth & 1 & $0.4 \%$ \\
\hline & Excess tobacco consumption & 120 & $47.8 \%$ \\
\hline & Chronic alcoholism & 1 & $0.4 \%$ \\
\hline Cause of oral cancer & All of the above & 128 & $51.0 \%$ \\
\hline & Not answered & 1 & $0.4 \%$ \\
\hline & Stopping tobacco usages & 35 & $13.9 \%$ \\
\hline & Chemotherapy & 17 & $6.8 \%$ \\
\hline Treatment of oral cancer & Radiotherapy & 2 & $0.8 \%$ \\
\hline & All of the above & 197 & $78.5 \%$ \\
\hline & Periodontal diseases & 12 & $4.8 \%$ \\
\hline & Oral cancer & 15 & $6.0 \%$ \\
\hline & Dental caries & 101 & $40.2 \%$ \\
\hline Fluorides are useful & All of the above & 113 & $45.0 \%$ \\
\hline & Not answered & 10 & $4.0 \%$ \\
\hline & Yes & 204 & $81.3 \%$ \\
\hline Use of toothpaste with & No & 5 & $2.0 \%$ \\
\hline fluoride & Don't know & 41 & $16.3 \%$ \\
\hline & Not answered & 1 & $0.4 \%$ \\
\hline & Reduces masticatory efficiency & 158 & $62.9 \%$ \\
\hline & Causes gingival diseases & 20 & $8.0 \%$ \\
\hline & Leads to dental decay & 27 & $10.8 \%$ \\
\hline If few teeth are missing & Don’t know & 38 & $15.1 \%$ \\
\hline & Not applicable & 8 & $3.2 \%$ \\
\hline & Removable appliance & 10 & $4.0 \%$ \\
\hline & Fixed appliance & 99 & $39.4 \%$ \\
\hline Options to ieplace lost & Both & 103 & $41.0 \%$ \\
\hline tooth & Don't know & 33 & $13.1 \%$ \\
\hline & Not answered & 6 & $2.4 \%$ \\
\hline & Painful & 25 & $10 \%$ \\
\hline & For regular checkup & 215 & $85.7 \%$ \\
\hline Visiting & When injured & 7 & $2.8 \%$ \\
\hline necessary & Don't know & 2 & $0.8 \%$ \\
\hline & Not answered & 2 & $0.8 \%$ \\
\hline
\end{tabular}


Table 4: Oral health related attitudes

Questions

$\begin{array}{lll} & \text { Regular brushing } & 42 \\ \text { How do you keep your } & \text { Regular rinsing } & 0 \\ \text { oral cavity clean } & \text { Both } & 209\end{array}$

Good habit
Cleaning with brush
Not a good habit
Don't know

\section{Frequency Percentage}

$\begin{array}{ll}42 & 16.7 \% \\ 0 & 0.0 \% \\ 209 & \mathbf{8 3 . 3} \%\end{array}$

249

$\mathbf{9 9 . 2 \%}$

$1 \quad 0.4 \%$

$1 \quad 0.4 \%$

$\begin{array}{ll}249 & \mathbf{9 9 . 2} \% \\ 1 & 0.4 \% \\ 1 & 0.4 \%\end{array}$

general health

\begin{tabular}{lllll} 
& & Yes & 248 & $\mathbf{9 8 . 8 \%}$ \\
Visiting dentist is & No & No & 2 & $0.8 \%$ \\
\cline { 3 - 4 } & & Don't know & 1 & $0.4 \%$
\end{tabular}

good habit

\begin{tabular}{|c|c|c|c|}
\hline \multirow{3}{*}{$\begin{array}{l}\text { Does dentist improve } \\
\text { your appearance }\end{array}$} & Yes & 238 & $94.8 \%$ \\
\hline & No & 3 & $1.2 \%$ \\
\hline & Don't know & 9 & $3.6 \%$ \\
\hline \multirow{4}{*}{$\begin{array}{l}\text { Do you want irregularly } \\
\text { positioned teeth to be }\end{array}$} & Yes & 217 & $86.5 \%$ \\
\hline & No & 26 & $10.4 \%$ \\
\hline & Don't know & 6 & $2.4 \%$ \\
\hline & Not answered & 2 & $0.8 \%$ \\
\hline
\end{tabular}

\begin{tabular}{|c|c|c|c|}
\hline \multirow{3}{*}{ Tobacco chewing } & Good habit & 1 & $0.4 \%$ \\
\hline & Bad habit & 248 & $98.8 \%$ \\
\hline & Don't know & 2 & $0.8 \%$ \\
\hline \multirow{4}{*}{$\begin{array}{l}\text { Wearing artificial } \\
\text { denture }\end{array}$} & Accepted & 216 & $86.1 \%$ \\
\hline & Not accepted & 17 & $6.8 \%$ \\
\hline & Don't know & 16 & $6.4 \%$ \\
\hline & Not answered & 2 & $0.8 \%$ \\
\hline
\end{tabular}

medical, dental and paramedical students of Mangalore, also showed that a greater portion of medical and paramedical students showed poor knowledge on the role of fluorides in dentifrices.

In our study, it was seen that $78.9 \%$ of the participants brush twice daily with $98 \%$ using toothbrush and toothpaste while in the study by Kaira LS et $\mathrm{al}^{3}$, only $48.7 \%$ brush twice daily with $70.2 \%$ using toothpaste. According to study by Udoye et $\mathrm{al}^{2}$ on nursing students of Nigerian tertiary hospital, however, only $43.4 \%$ brush more than once and $53.7 \%$ brush once daily. Study by Darout IA et $\mathrm{al}^{4}$ conducted among Jimma
University Health Sciences students of Ethopia, only $23.3 \%$ of males and $34.4 \%$ of females brush at least twice or more. In a study by Alsrour et $\mathrm{al}^{8}$ in Jordan, it was seen that $61 \%$ of students brush at least twice a day where $92.2 \%$ use fluoridated toothpaste with $49.3 \%$ replacing their toothbrush every one to three months.

Only $10 \%$ of the participants in our study used dental floss, similar to $13.5 \%$ in a study by Kaira LS et $\mathrm{al}^{3}, 30 \%$ in study by Kakkad et $\mathrm{al}^{9}$ conducted among engineering students it was less than $35 \%$ according to Baseer et al. ${ }^{10}$ Thus, it seems that with regards to regular flossing attitudes of the students 
Table 5: Showing frequency of tooth brushing

$\begin{array}{llll}\text { Question } & & \text { Frequency } & \text { Percentage } \\ \text { How many times do you brush } & \text { Once } & 27 & 10.8 \% \\ \text { your teeth? } & \text { Twice } & 198 & \mathbf{7 8 . 9 \%} \\ & \text { Thrice } & 21 & 8.4 \% \\ & \text { After every meal } & 4 & 1.6 \% \\ & \text { Not answered } & 1 & 0.4 \%\end{array}$

Table 6: Agent for tooth brushing

$\begin{array}{llll}\text { Question } & & \text { Frequency } & \text { Percentage } \\ \text { What do you use to brush your } & \text { Toothpaste } & 246 & \mathbf{9 8 \%} \\ \text { teeth? } & \text { Neemstick } & 1 & 0.4 \% \\ & \text { Salt } & 3 & 1.2 \% \\ & \text { Not answered } & 1 & 0.4 \%\end{array}$

Table 7: Other aids used to clean oral cavity

$\begin{array}{llll}\text { Question } & & \text { Frequency } & \text { Percentage } \\ \text { Other aids used to clean oral } & \text { Dental floss } & 25 & 10 \% \\ \text { cavity } & \text { Tongue cleaner } & 87 & 34.7 \% \\ & \text { Mouth rinse } & 205 & \mathbf{8 1 . 6 \%} \\ & \text { Interdental brush } & 6 & 2.4 \% \\ & \text { Not answered } & 9 & 3.6 \%\end{array}$

Table 8: Brushing technique

$\begin{array}{llll}\text { Question } & & \text { Frequency } & \text { Percentage } \\ \text { How do you brush your teeth? } & \text { Horizontally } & 10 & 4.0 \% \\ & \text { Vertically } & 8 & 3.2 \% \\ & \text { Circularly } & 23 & 9.2 \% \\ & \text { Combination of these } & 208 & \mathbf{8 2 . 9 \%} \\ & \text { Not answered } & 2 & 0.8 \%\end{array}$

Table 9: Table showing what is used by the students to rinse the mouth

$\begin{array}{llll}\text { Question } & & \text { Frequency } & \text { Percentage } \\ \text { What do you use to rinse your } & \text { Plain water } & 190 & \mathbf{7 5 . 7 \%} \\ \text { mouth? } & \text { Mouthwash only } & 5 & 2.0 \% \\ & \text { Water and mouth wash } & 55 & 21.9 \% \\ & \text { Not answered } & 1 & 0.4 \%\end{array}$

Table 10: Frequency of visiting the dentist

\begin{tabular}{llll} 
Question & & Frequency & Percentage \\
How often do you visit your & Once a year & 62 & $24.7 \%$ \\
dentist? & Twice a year & 29 & $11.6 \%$ \\
& Once in two years & 11 & $4.4 \%$ \\
& When there is problem & 147 & $\mathbf{5 8 . 6 \%}$ \\
& Not answered & 2 & $0.8 \%$ \\
\hline
\end{tabular}


have to be improved. $58.6 \%$ of participants in our study visit dentists only in case of any problem similar to Kaira LS et $\mathrm{al}^{3}$ where $49.5 \%$ visit dentist only in case of pain.

Health promotion in developing country like Nepal is limited due to geographic, social, economic and political factors leading to inadequate health care resources. ${ }^{11}$ According to study by Harikiran et a ${ }^{12}$ conducted on 11-12 year old school children in a government aided missionary school in Bangalore, $36.3 \%$ had knowledge on fluoride preventing tooth decay similar to our study where the percentage was $40.2 \%$. Study by Sharda et $\mathrm{al}^{13}$ comparing oral health knowledge between BDS first and final year students suggested $51.6 \%$ of first year students while $98.7 \%$ of final year students had knowledge on effect of sweet retention on teeth. It was seen that in study by Harikiran et al ${ }^{12} 75.1 \%$ thought brushing prevents tooth decay similar to our study where it was $84.9 \%$. However, only $48.9 \%$ had knowledge that sweets cause dental decay in contrast to our study where it was $82.5 \%$. Only $38.5 \%$ brush twice daily while only $4.6 \%$ use dental floss. The children who were aware of the importance of regular dental visits were $67.8 \%$ while only $35.1 \%$ have reported that they have visited a dentist recently.

The scientific literature provides us an overview regarding impact of oral health knowledge, attitude and oral health behavior on oral diseases. Collection of such data is helpful in carrying out various programs to train this important group of manpower to utilize their services in the field of oral health. When interpreting the results of the present study, several limitations have to be considered. Over-reporting of proper hygiene practices is a likely limitation since the students' report of their behavior by themselves.

\section{CONCLUSION}

This study presented an overview on oral health related knowledge, attitude and practice of nursing students of Kathmandu district which was satisfactory with deficiency in knowledge about oral cancer, fluorides, dental flossing and prosthetic rehabilitation. Therefore, to fill this void and bridge this gap, further improvements can be encouraged and facilitated through integration of oral health in their curriculum or through orientation and training programs. These auxiliaries can therefore be of use in dissemination of dental health related knowledge to the public.

\section{ACKNOWLEDGEMENT}

We would like to acknowledge the nursing students and the authorities of the Nursing Colleges for giving us the permission to work in their institutes and Kantipur Dental College for the help and support.

\section{REFERENCES}

1. Park K. Textbook of Preventive and Social Medicine. 23rd edition. M/s Banarsidas Bhanot publishers. 2015.

2. Udoye C, Aguwa E. Oral Health Related Knowledge and Behavior Among Nursing Students in a Nigerian Tertiary Hospital. The Internet Journal of Dental Science. 2008;7 (2).

3. Kaira LS, Srivastava V, Giri P, Chopra D. Oral healthrelated knowledge, attitude and practice among nursing students of Rohilkhand Medical College and Hospital. Journal of Orofacial Research. 2012;2(1):20-3.

4. Darout IA. Article O. Knowledge and behavior related to oral health among Jimma University Health Sciences students , Jimma , Ethiopia. European Journal of General Dentistry. 2014;3(3):185-9. DOI: $\quad 10.4103 / 2278-$ 9626.141663.

5. Senthil M, Padma K. Bhat. Oral Health Knowledge and Attitude among final year nursing undergraduate students in Bangalore city, India. Journal of Indian Association of Public Health Dentistry. 2011;17(Supp I):389-96.

6. Amith HV, D'Cruz AM, Shirahatti RV. Oral Health Knowledge and Practices among Rural Government Primary School Teachers of Mangalore, Karnataka. Journal of Indian Association of Public Health Dentistry. 2013;11(3):63-.7

7. Usman S, Bhat SS, Sargod SS. Knowledge OH, Students P, Mangalore I. Oral Health Knowledge and Behavior of Clinical Medical, Dental and Paramedical Students In Mangalore. Journal of Oral Health Comm Dent. 2007;1 (3):46-8.

8. Alsrour SS, Nassrawin N, Al-Tawarah YM. Oral health knowledge, attitudes and behavior of nursing students at Mutah university (Jordan). Pakistan Oral \& Dental Journal. 2013;33(1):102-9.

9. Kakkad DN, Murali R, Krishna M, Yadav S, Yalamalli M, Kumar AV. Assessment of Oral Hygiene Knowledge Attitude , and Practices among Engineering Students in North Bangalore: A Cross-sectional Survey. International Journal of Scientific Study. 2015;3(1):84-9.

10. Baseer MA, Alenazy MS, Alasqah M, Algabbani M, Mehkari A. Oral health knowledge, attitude and practices among health professionals in King Fahad Medical City , Riyadh. Dental Research Journal. 2012;9(4):386-92.

11. Humagain M. Evaluation Of Knowledge, Attitude And Practice ( KAP ) About Oral Health Among Secondary Level Students Of Rural Nepal - A Questionnaire Study. WebmedCentral Dentistry. 2011;2(3):1-17.

12. Harikiran AG, Pallavi SK, Hariprakash S, Nagesh KS. Oral health-related KAP among 11-to 12-year-old school children in a government-aided missionary school of Bangalore city. Indian Journal of Dental Research. 2008;19(3):236. DOI: 10.4103/0970-9290.42957. PMID:18797101. 
13. Sharda AJ, Shetty S. A comparative study of oral health knowledge, attitude and behaviour of first and final year dental students of Udaipur city, Rajasthan, India. International journal of dental hygiene. 2008;6(4):347-53.

DOI: $10.1111 /$ j.1601-5037.2008.00308.x.

PMID: 19138186 